\title{
FAKTOR SOSIAL DAN FAKTOR EKONOMI PADA USAHATANI MANGGA SERTA PENGARUHNYA TERHADAP PEMASARAN MANGGA (Studi Kasus Di Dua Daerah Sentra Produksi Mangga di Jawa Barat)
}

\author{
SOCIAL FACTORS AND ECONOMIC FACTORS ON MANGO FARMING \\ AND THEIR EFFECT ON MANGO MARKETING \\ (Case Study in Two Mango Production Center Areas in West Java)
}

\author{
Elly Rasmikayati ${ }^{1}$, Muhammad Nugroho Bayu Utomo Sumarsah ${ }^{1}$, Dika Supyandi ${ }^{1}$, \\ Adi Nugraha ${ }^{1}$, Bobby Rachmat Saefudin ${ }^{2 *}$ \\ ${ }^{1}$ Fakultas Pertanian, Universitas Padjadjaran, Jl. Ry Bandung-Sumedang KM.21 Jatinangor, 45363 \\ ${ }^{2}$ Fakultas Pertanian, Ma'soem University, Jl. Raya Cipacing No. 22 Jatinangor, 45363 \\ *E-mail: bobbyrachmat@masoemunversity.ac.id \\ (Diterima 29-06-2021; Disetujui 22-07-2021)
}

\begin{abstract}
ABSTRAK
Kegiatan pemasaran yang dilakukan oleh petani mangga dapat dipengaruhi oleh berbagai faktor. Faktor tersebut diantaranya adalah faktor sosial maupun faktor ekonomi. Tujuan dari penelitian ini adalah untuk mengidentifikasi faktor sosial, faktor ekonomi, dan subsistem pemasaran mangga di Kecamatan Cikedung dan Kecamatan Japara, dan menganalisis pengaruh dari faktor sosial dan faktor ekonomi terhadap pemasaran mangga di kedua daerah tersebut. Penelitian ini menggunakan menggunakan metode survey kepada 260 petani mangga di Kecamatan Cikedung dan Kecamatan Japara. Alat analisis yang digunakan dalam penelitian ini yaitu analisis statistika deskripsi dan regresi linier berganda. Hasil penelitian menunjukkan bahwa variabel-variabel faktor sosial dan ekonomi di kedua kecamatan berada dalam kondisi baik. Sementara dalam pemasaran mangga, kecamatan Cikedung relatif lebih baik dari kecamatan Japara. Faktor sosial berpengaruh signifikan terhadap pemasaran mangga di kecamatan Cikedung, sedangkan faktor ekonomi tidak berpengaruh. Di kecamatan Japara, faktor sosial dan ekonomi tidak berpengaruh terhadap pemasaran mangga.
\end{abstract}

Kata kunci: Faktor sosial, faktor ekonomi, subsistem pemasaran, buah, mangga

\begin{abstract}
Marketing activities carried out by mango farmers can be influenced by various factors. These factors include social factors and economic factors. The purpose of this study was to identify social factors, economic factors and mango marketing subsystems in Cikedung and Japara sub-districts and to analyze the influence of social and economic factors on mango marketing in both areas. This study uses a survey method to 260 mango farmers in Cikedung and Japara sub-districts. The analytical tools used in this research are descriptive statistis analysis and multiple linear regression. The results showed that the variables of social and economic factors in the two subdistricts were in good condition. Meanwhile, in mango marketing, Cikedung sub-district is relatively better than Japara sub-district. Social factors have a significant effect on mango marketing in Cikedung sub-district, while the economic factors have no effect. In the district of Japara sub-district, social and economic factors have no effect on mango marketing.
\end{abstract}

Keywords: Social factors, economic factors, marketing subsystem, fruit, mango 


\section{PENDAHULUAN}

Provinsi Jawa Barat sebagai salah satu sentra produksi mangga di Indonesia, Jawa Barat mempunyai luas panen terkecil dibandingkan dengan Jawa Timur dan Jawa Tengah, tetapi Jawa Barat mempunyai produktivitas terbesar dengan produktivitas sebesar 14,31 ton/ha pada tahun 2018 dibandingkan dengan provinsi Jawa Timur dengan produktivitas sebesar 12,71 ton/ha dan Jawa Tengah dengan produktivitas sebesar 12,06 ton/ha (BPS, 2019). Hal ini menunjukan bahwa kegiatan produksi mangga di Jawa Barat lebih produktif dibandingkan dengan daerah sentra produksi mangga lainya. Jawa Barat memiliki lima daerah sentra produksi mangga, yaitu Kabupaten Indramayu, Sumedang, Cirebon, Majalengka dan Kuningan.

Tabel 1. Produksi Mangga di Sentra Mangga Jawa_Barat Tahun 2018

\begin{tabular}{clcc}
\multicolumn{4}{c}{ Jawa_Barat Tahun 2018 } \\
\hline No. & Kabupaten & $\begin{array}{c}\text { Produksi } \\
\text { tahun 2018 }\end{array}$ & $\begin{array}{c}\text { \% Produksi } \\
\text { Jawa Barat }\end{array}$ \\
\hline 1 & Indramayu & 941,147 & 31.08 \\
2 & Majalengka & 447,567 & 14.78 \\
3 & Cirebon & 554,767 & 18.32 \\
4 & Kuningan & 348,506 & 11.51 \\
5 & Sumedang & 735,821 & 24.30 \\
\hline
\end{tabular}

Sumber: Dinas Tanaman Pangan dan Holtikultura Jawa Barat (2020)

Berdasarkan Tabel 1, produksi mangga di lima daerah sentra mangga di Jawa Barat memiliki perbedaan yang cukup besar antara satu daerah dengan lainnya, terlebih pada Kabupaten Indramayu dan Kabupaten Kuningan. Berdasarkan informasi pada Tabel 1, produksi mangga di Kabupaten Indramayu mencapai 941.147 kuintal pada tahun 2018 yang menjadikan Kabupaten Indramayu sebagai kabupaten yang memproduksi mangga terbesar di wilayah Jawa Barat. Kabupaten Indramayu memiliki 31 kecamatan, salah satunya adalah Kecamatan Cikedung. Kecamatan Cikedung merupakan salah satu Kecamatan yang memiliki potensi mangga terbesar di Kabupaten Indramayu. Pada tahun 2019 Kecamatan Cikedung mampu memproduksi 96.000 kuintal mangga yang menjadikan Kecamatan Cikedung sebagai Kecamatan produsen mangga terbesar di Indramayu.

Tabel 2. Lima Besar Kecamatan Dengan Produksi Mangga Terbesar di Indramayu Tahun 2018-2019

\begin{tabular}{|c|c|c|c|}
\hline \multirow{2}{*}{ No } & \multirow{2}{*}{ Kecamatan } & \multicolumn{2}{|c|}{ Produksi Mangga (Kw) } \\
\hline & & 2018 & 2019 \\
\hline 1 & Haurgeulis & 97.810 & 86.944 \\
\hline 2 & Cikedung & 53.194 & 96.071 \\
\hline 3 & Anjatan & 68.427 & 53.447 \\
\hline 4 & Jatibarang & 78.459 & 52.813 \\
\hline 5 & Kroya & 70.112 & 56.065 \\
\hline & $\begin{array}{l}\text { Badan P } \\
\text { Indramayu }\end{array}$ & $\begin{array}{l}\text { Statistik } \\
020)\end{array}$ & Kabupaten \\
\hline
\end{tabular}

Sementara itu, Kabupaten Kuningan yang menjadi daerah sentra produksi mangga terendah di Jawa Barat hanya mampu memproduksi 348.506 
kuintal mangga pada tahun 2018. Kabupaten Kuningan sendiri memiliki 32 kecamatan yang memproduksi mangga, salah satunya adalah Kecamatan Japara. Kecamatan Japara merupakan salah satu produsen mangga terbesar di Kuningan yang mampu memproduksi 35.980 kuintal mangga pada tahun 2019 (BPS, 2020).

Tabel 3. Lima Besar Kecamatan dengan Produksi Terbesar di Kuningan Tahun 2018-2019

\begin{tabular}{|c|c|c|c|}
\hline \multirow{2}{*}{ No } & \multirow{2}{*}{ Kecamatan } & \multicolumn{2}{|c|}{$\begin{array}{c}\text { Produksi Mangga } \\
(\mathrm{Kw})\end{array}$} \\
\hline & & 2018 & 2019 \\
\hline 1 & Japara & 592 & 35.988 \\
\hline 2 & Kalimanggis & 46.500 & 38.456 \\
\hline 3 & Hantara & 37.200 & 29.875 \\
\hline 4 & Ciwaru & 15.061 & 29.756 \\
\hline 5 & Ciawigebang & 24.358 & 25.630 \\
\hline & $\begin{array}{ll}\text { er: } & \text { Badan P } \\
& \text { Kuningan }\end{array}$ & Statistik & bupaten \\
\hline
\end{tabular}

Kedua kecamatan tersebut memiliki peningkatan produksi terbesar di antara kecamatan lainnya dan memberikan produksi yang besar bagi Kabupaten Indramayu dan Kabupaten Kuningan. Tingkat produksi yang besar memberikan peluang pemasaran yang besar bagi buah mangga dan para produsen mangga. Kegiatan pemasaran memungkinkan, mendorong dan memberi kemudahan dalam melakukan transaksi sehingga petani bisa memiliki pendapatan yang lebih tinggi (Shinta, 2001). Menurut Kusumo dkk. (2019), lebih dari separuh petani mangga di Kabupaten Indramayu (55\%) menjual hasil panen nya ke tengkulak atau bandar, sementara 26\% petani memilih untuk menjual mangga dengan sistem tebasan dan ijon. Berdasarkan penelitian yang dilakukan oleh Yuliawati (2018). saluran pemasaran produk pertanian di Kabupaten Kuningan mulai dari tempat produksi sampai pemasaran terbagi menjadi dua pola. Pola yang pertama adalah saluran pemasaran satu tingkat (petani - pedagang pengecer) dan saluran pemasaran tiga tingkat (petani - pedagang pengumpul pedagang besar - pedagang pengecer). Dalam melakukan kegiatan pemasaran, petani di Kecamatan Cikedung dan Kecamatan Japara masih banyak yang menjual produknya kepada pedagang pengumpul/tengkulak.

Mayoritas petani mangga di Kecamatan Japara dalam menjual produk mereka memilih sistem penjualan dengan cara kontrak atau dengan cara memborongkan pohon mangga ke tengkulak. Petani melakukan hal tersebut karena pertumbuhan tengkulak yang semakin banyak di Kecamatan Japara dan dalam membeli produk dari petani biasanya tengkulak menawarkan dengan cara mengontrak atau diborong saja (Rasmikati dkk., 2019). Ketika menjual 
produknya melalui pedagang pengumpul/ tengkulak, petani menjadi terikat ketika menentukan harga untuk produk yang dijual, hal ini dapat disebabkan karena posisi petani juga seringkali lemah dalam penentuan harga jual mangga (Supriatna, 2008). Selain itu, informasi pasar yang dimiliki oleh petani rendah yang menyebabkan petani kesulitan dalam melakukan kegiatan pemasaran. Menurut Rasmikayati dkk. (2019), mayoritas petani di Kabupaten Indramayu sudah memiliki informasi harga pasar.

Petani dalam melakukan kegiatan pemasaran dapat dipengaruhi oleh berbagai faktor, yaitu tingkat pendidikan yang diterima oleh petani, frekuensi petani dalam mengikuti penyuluhan, akses petani terhadap informasi pemasaran mangga, syarat untuk memasuki pasar yang mudah, tingkat hasil panen dengan kualitas baik serta keterikatan petani terhadap sumber pembiayaan tertentu mempengaruhi secara signifikan terhadap keputusaan petani mangga di Kabupaten Indramayu dalam melakukan kegiatan pemasaran (Rasmikayati dkk., 2019). Selain faktorfaktor tersebut, kedekatan petani dengan pedagang pengumpul menjadi pertimbangan tersendiri bagi petani dalam memilih pasar. Produsen yang memiliki akses informasi pasar mengenai harga, kualitas, warna, kuantitas dan tempat pasar tidak memilih bandar karena bandar memberikan harga yang lebih rendah untuk produk mangga yang dijual oleh petani (Kabeta, 2018).

Banyak dari petani mangga di Kecamatan Cikedung dan Japara yang masih menerapkan sistem tebasan atau ijon dalam menjual produknya. Selain itu, petani di Japara juga masih banyak yang menjual produknya melalui pedagang pengumpul/tengkulak hal ini yang mengakibatkan petani tidak bisa menentukan harga untuk hasil panen buah mangga mereka karena harga sudah ditentukan oleh pembeli. Selain itu, minimnya informasi harga yang dimiliki oleh petani juga membuat petani tidak bisa mengetahui harga pasar. Kegiatan pemasaran yang dilakukan oleh petani dapat dipengaruhi oleh berbagai faktor. Faktor tersebut diantaranya adalah faktor sosial maupun faktor ekonomi. Berbagai faktor tersebut akan mempengaruhi petani dalam memilih kegiatan pemasaran yang dilakukan oleh petani. Berdasarkan pemaparan tersebut, maka tujuan dari penelitian ini adalah: 1) untuk mengidentifikasi faktor sosial, faktor ekonomi dan subsistem pemasaran 
mangga di Kecamatan Cikedung dan Kecamatan Japara; dan 2) Menganalisis pengaruh dari faktor sosial dan faktor ekonomi terhadap pemasaran mangga di kedua daerah tersebut.

\section{METODE PENELITIAN}

Objek yang menjadi bahan penelitian pada penelitian adalah subsistem pemasaran dan faktor yang mempengaruhi pemasaran manga, yaitu faktor sosial dan ekonomi. Lokasi yang dipilih adalah Kecamatan Cikedung, Kabupaten Indramayu dan Kecamatan Japara, Kabupaten Kuningan secara sengaja karena karena memiliki potensi terbesar di bandingkan kecamatan lain di Kabupaten Indramayu dan Kabupaten Kuningan. Desain yang digunakan pada penelitian ini adalah penelitian kuantitatif. Metode penelitian yang digunakan adalah metode survey dan studi literatur.

Variabel dalam penelitian ini meliputi:

\section{Faktor Sosial}

a. Rutinitas petani melakukan diskusi/sharing antara petani mangga adalah seberapa sering petani mangga melakukan kegiatan diskusi yang dilakukan antar petani manga. b. Besarnya partisipasi/kerja sama masyarakat dalam usahatani mangga adalah seberapa besar ketelibatan masyarakat dalam usahatani mangga yang dilakukan oleh petani.

c. Minimnya konflik dalam masyarakat adalah seberapa kecil pertentangan yang dialami petani atau usahatani dengan masyarakat.

\section{Faktor Ekonomi}

a. Kemudahan akses terhadap modal adalah seberapa mudah petani untuk mendapatkan modal yang dibutuhkan untuk menjalankan kegiatan usahatani.

b. Tingginya permintaan mangga adalah seberapa besar permintaan mangga dari konsumen.

c. Harga jual tinggi adalah apakah harga jual buah mangga petani dirasa sudah cukup besar/tinggi.

3. Subsistem Pemasaran

a. Pemilihan Pasar adalah kemana petani menjual produk hasil usahatani yang dilakukan.

b. Kondisi Jalan adalah keadaan jalan dari kebun mangga milik petani ke jalan utama.

c. Penetapan Harga adalah siapa yang menentukan harga hasil panen yang akan dijual. 
d. Sistem Pemabayaran adalah bagaimana petani menentukan sistem pembayaran yang dilakukan dalam menjual produknya.

e. Informasi Harga Pasar adalah apakah petani mengetahui tentang informasi harga buah mangga di pasaran.

Populasi pada penelitian ini adalah petani mangga di Kecamatan Cikedung dan Japara. Pengambilan sampel menggunakan teknik simple probability sampling sedemikian rupa sehingga didapatkan sampel untuk tiap kecamatan masing-masing sebanyak 130 responden.

Rancangan analisis data pada penelitian ini meliputi:

\section{Analisis Deskriptif}

Pada penelitian kali ini teknik analisis deskriptif digunakan untuk menganalisis data dengan mendeskripsikan dan menghubungkan data untuk membuat kesimpulan umum

Analisis deskriptif digunakan untuk mendeskripsikan subsistem pemasaran serta faktor sosial dan faktor ekonomi di Kabupaten Indramayu dan Kuningan. Data disajikan dalam bentuk tabel distribusi frekuensi dan grafik/diagram.

\section{Analisis Regresi Berganda}

Analisis regeresi berganda digunakan untuk melihat pengaruh faktor sosial ekonomi terhadap subsistem pemasaran. Persamaan regresi tersebut yaitu sebagai berikut:

$$
\mathrm{Y}=a+\beta_{1} X_{1}+\beta_{2} X_{2}+\varepsilon
$$

Keterangan:

$\mathrm{Y}=$ Subsistem pemasaran kecamatan

$\mathrm{a}=$ Konstanta

$X_{1}=$ Faktor sosial kecamatan

$X_{2}=$ Faktor ekonomi kecamatan

$\beta=$ Koefisien regresi

$\varepsilon=$ error term

Sebelum melakukan analisis regresi berganda tersebut sebelunya akan dilakukan dahulu uji validitas, reliabilitas dan asumsi klasik, uji kecocokan model, uji $\mathrm{F}$ dan uji $\mathrm{T}$.

\section{HASIL DAN PEMBAHASAN}

\section{Deskripsi Faktor Sosial di Kecamatan Cikedung dan Kecamatan Japara}

Faktor sosial terdiri atas 3 variabel, yaitu rutinitas diskusi antar petani mangga, kerja sama yang dilakukan antar petani mangga dan jarang terjadi konflik antar masyarakat dan petani mangga.

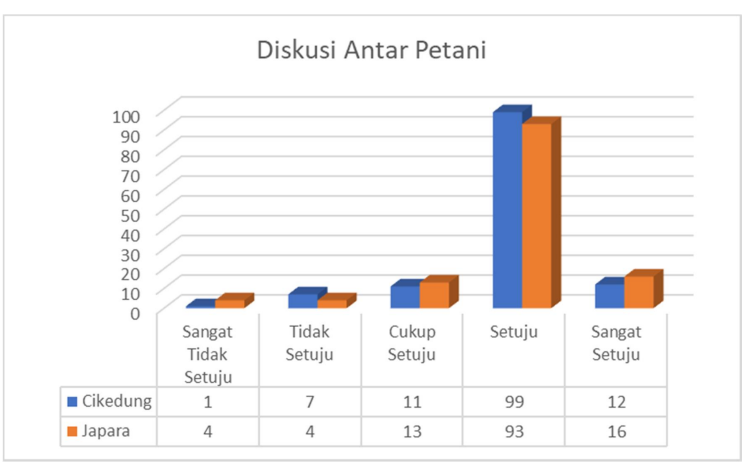

Gambar 1. Rutinitas Diskusi Antar Petani 
Sebagaimana tersaji pada Gambar 1, mayoritas petani mangga di Kecamatan Cikedung (76\%) dan Kecamatan Japara (72\%) setuju bahwa mereka sering melakukan diskusi atau berbagi ilmu antar sesama petani mangga lainnya demi agar dapat mencapai keberhasilan usaha mangga secara bersama-sama.

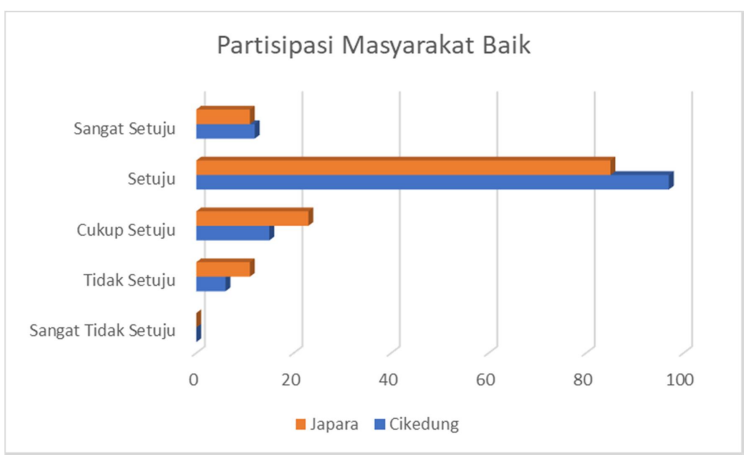

\section{Gambar 2. Partisipasi Masyarakat} di Lingkungan Usahatani

Mayoritas petani mangga di Kecamatan Cikedung (75\%) dan Kecamatan japara (65\%) setuju bahwa partisipasi atau kerjasama masyarakat atau petani mangga sudah terjalin dengan baik di lingkungan usahatani di kecamatan Cikedung dan kecamatan Japara dan hanya sedikit petani yang tidak setuju (Gambar 2).

Berdasarkan Gambar 3, sebagian besar petani di Kecamatan Cikedung dan Kecamatan Japara setuju bahwa konflik yang dapat mengganggu kegiatan usahatani yang dilakukan oleh petani jarang terjadi di masyarakat dan hanya sebagian kecil petani yang tidak setuju dengan hal tersebut.

\section{Deskripsi Faktor Ekonomi di Kecamatan Cikedung dan Kecamatan Japara}

Faktor ekonomi terdiri atas 3 variabel yaitu kemudahan akses terhadap modal, tingginya permintaan mangga dan harga jual mangga tinggi.

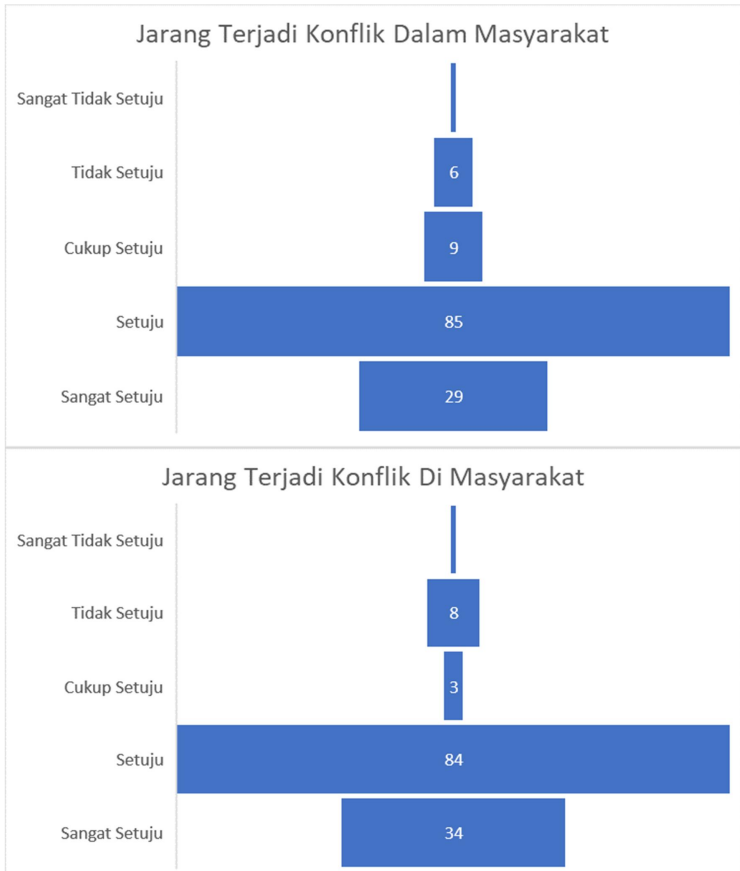

Gambar 3. Konflik Yang Terjadi di Masyarakat Petani Kecamatan Cikedung (Atas) dan Japara (Bawah)

Berdasarkan Gambar 4, dapat dilihat, bahwa sebagian besar petani mangga di Kecamatan Cikedung (48\%) dan kecamatan Japara (61\%) setuju bahwa akses terhadap modal mudah untuk didapatkan oleh petani di kedua kecamatan tersebut. $25 \%$ petani di kecamatan Cikedung dan 27\% petani di kecamatan Japara juga sangat setuju 
bahwa akses modal mudah untuk di dapatkan oleh petani.

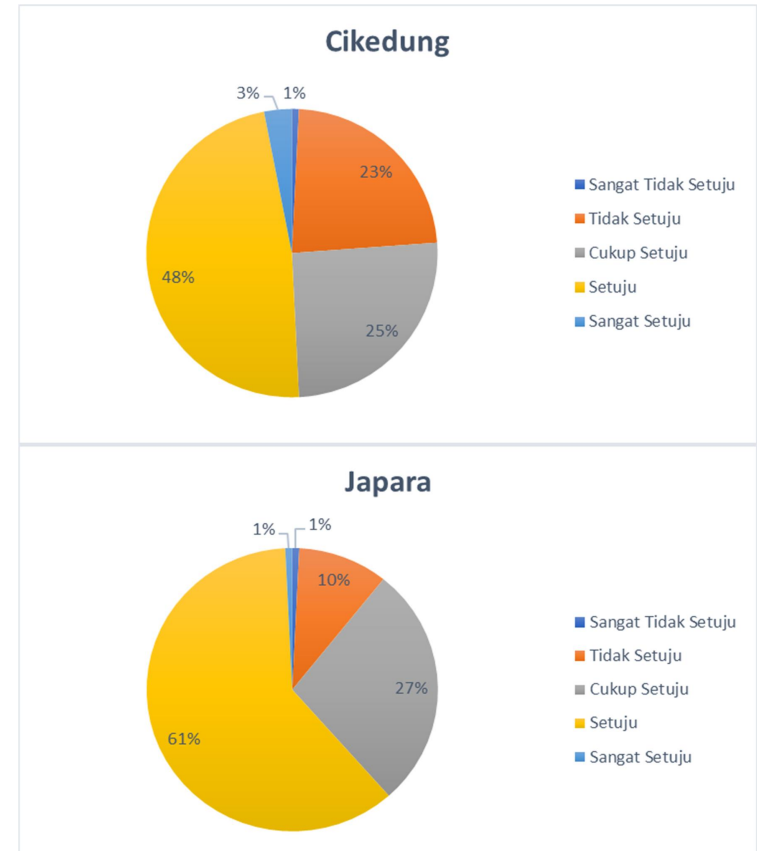

Gambar 4. Kemudahan Akses Modal Petani Cikedung (Atas) dan Petani Japara (Bawah)

Berdasarkan Gambar 5, mayoritas petani mangga di Kecamatan Cikedung dan Kecamatan Japara menyatakan setuju apabila permintaan konsumen terhadap mangga tinggi sehingga banyak petani yang menganggap usahatani mangga ini layak untuk dilakukan. Petani yang tidak setuju dengan permintaan konsumen terhadap mangga tinggi hanya di bawah 5\% baik di Kecamatan Cikedung maupun Kecamatan Japara.

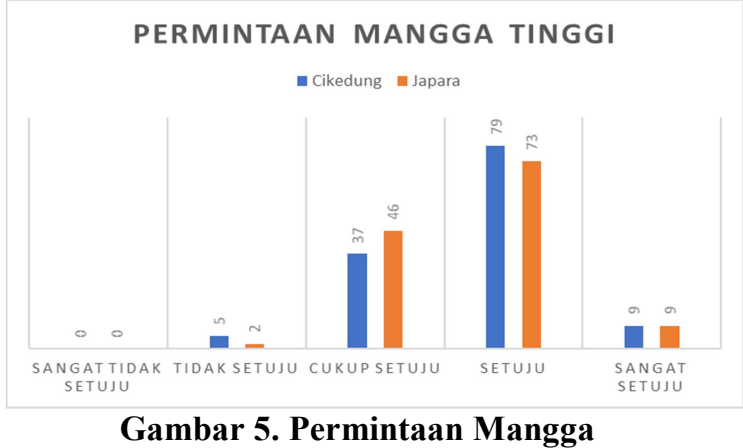

Gambar 5. Permintaan Mangga

Berdasarkan Gambar 6, mayoritas petani mangga di Kecamatan Cikedung dan Kecamatan Japara menyatakan setuju apabila harga jual mangga tinggi sehingga banyak petani yang menganggap usahatani mangga ini layak untuk dilakukan. Tetapi ada sebagian petani di Kecamatan Cikedung (14\%) dan Kecamatan Japara (12\%) yang tidak setuju bahwa harga jual buah mangga tinggi.

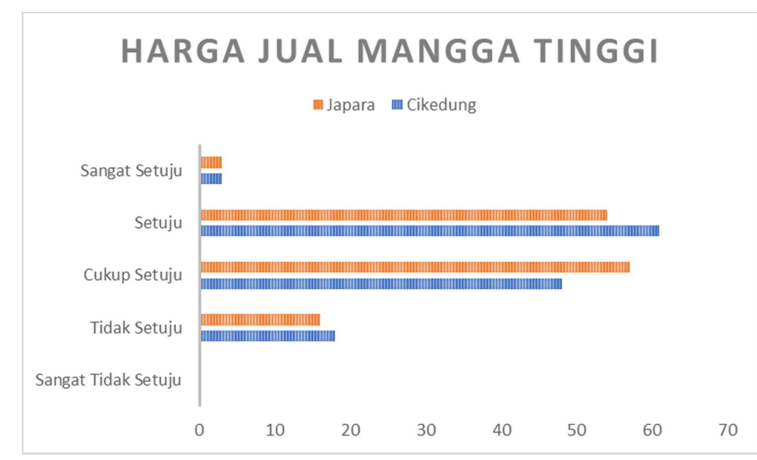

Gambar 6. Harga Jual Mangga Tinggi

\section{Deskripsi Subsistem Pemasaran di Kecamatan Cikedung dan Kecamatan Japara}

Subsistem pemasaran mangga terdiri atas 5 variabel, yaitu pemilihan pasar petani, kondisi jalan dari kebun ke jalan utama, sistem pembayaran, 
informasi harga pasar dan penetapan harga.

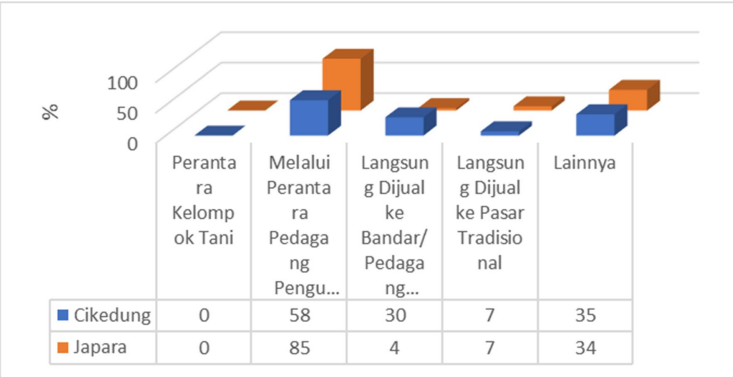

Gambar 7. Pemilihan Pasar Petani

Berdasarkan Gambar 7, dapat dilihat bahwa sebagian besar petani mangga di Kecamatan Cikedung (58\%) dan kecamatan Japara (85\%) menjual mangganya ke perantara dan pedagang pengumpul.

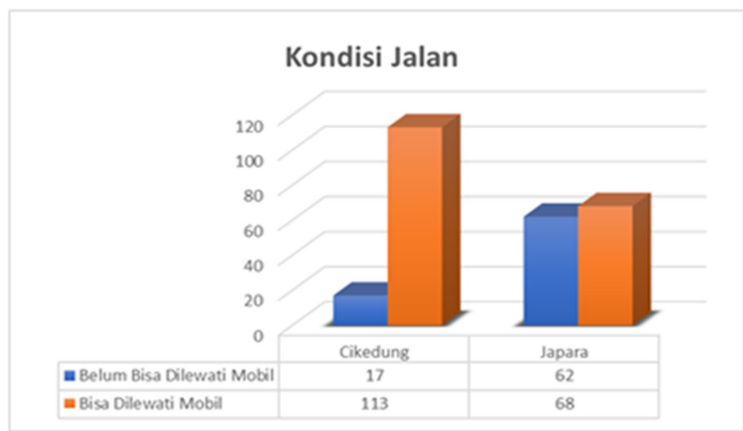

Gambar 8. Kondisi Jalan dari Kebun ke Jalan Utama

Berdasarkan Gambar 8, dapat dilihat bahwa, sebagian besar petani mangga di Kecamatan Cikedung (113 orang) menyatakan bahwa kondisi jalan sudah bisa dilewati mobil, sedangkan di kecamatan Japara hanya 68 orang yang menyatakan hal tersebut.

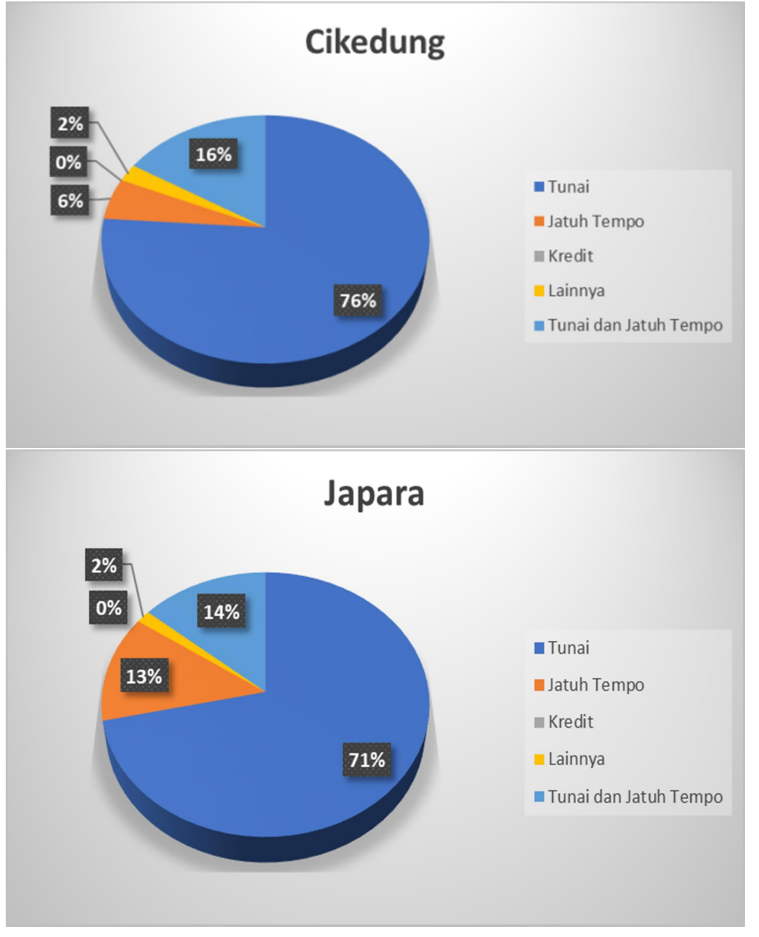

Gambar 9. Sistem Pembabayaran

Berdasarkan Gambar 9, dapat dilihat bahwa sistem pembayaran mangga di kedua kecamatan hampir sama. Mereka mayoritas lebih memilih sistem pembayaran tunai. Hanya sebagian kecil saja yang menggunakan sistem pembayaran jatuh tempo, kredit dan lainnya.

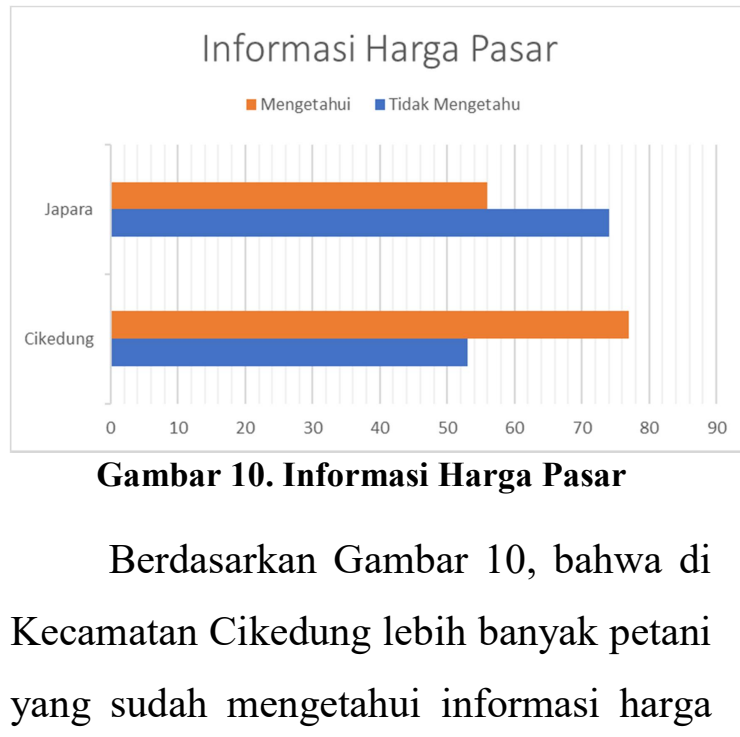


pasar, sedangkan sebaliknya di Kecamatan Japara lebih banyak yang belum mendapatkan informasi harga pasar.

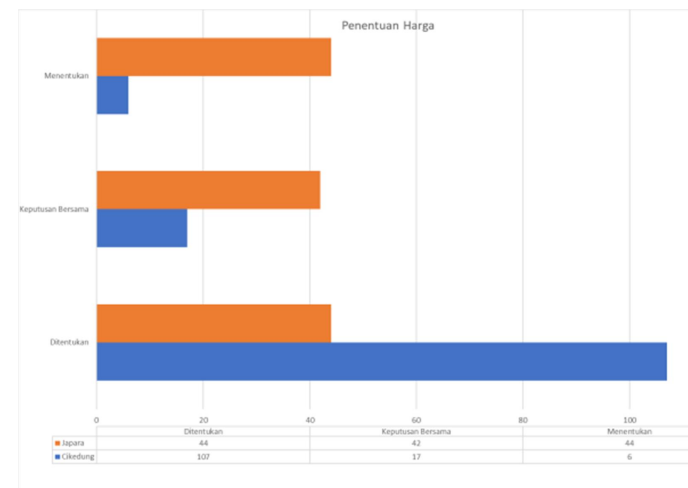

Gambar 11. Penetapan Harga

Berdasarkan Gambar 11, dapat dilihat bahwa sebagian besar penentuan harga jual mangga di Kecamatan Cikedung ditentukan oleh pembeli, sedangkan di Kecamatan Japara proporsinya hampir merata antara ditentukan petani, kesepakatan bersama dan ditentukan penjual.

\section{Pengaruh Faktor Sosial dan Faktor Ekonomi terhadap Pemasaran Mangga di Kecamatan Cikedung dan Kecamatan Japara}

\section{Tes Asumsi Klasik}

\section{1) Uji Multikolinearitas}

Menurut Ghozali (2012), uji multikolinearitas bertujuan untuk menguji apakah suatu model regresi terdapat korelasi antar variabel bebas (independen). Model regresi yang baik seharusnya tidak terjadi korelasi antar variabel independen. Model analisis regresi yang baik harus bebas dari multikolinearitas atau tidak memiliki korelasi yang tinggi antar variabel independen. Cara terbaik untuk mendeteksi ada atau tidak adanya multikolinearitas adalah untuk melihat toleransi dan Variance Inflation Factor (VIF). Jika nilai toleransi $>0,5$ dan nilai VIF $<5$, maka dapat disimpulkan bahwa tidak terdapat multikolinearitas antar variabel independen pada model regresi.

Tabel 4. Hasil Uji Multikolinearitas

\begin{tabular}{lcc}
\hline \multirow{1}{*}{ Variabel } & \multicolumn{2}{c}{$\begin{array}{c}\text { Collinearity } \\
\text { Statistics }\end{array}$} \\
\cline { 2 - 3 } & Tolerance & VIF \\
\hline Faktor Sosial Cikedung & 0.897 & 1.115 \\
Faktor Ekonomi & 0.897 & 1.115 \\
Cikedung & & \\
\hline Faktor Sosial Japara & 0.981 & 1.020 \\
Faktor Ekonomi Japara & 0.981 & 1.020 \\
\hline Sumber: Data Primer, diolah 2021 &
\end{tabular}

Berdasarkan Tabel 4, seluruh variabel pada Kecamatan Cikedung dan Kecamatan Japara memiliki nilai VIF $<5$ dan nilai tolerance $>0,5$ Sehingga dapat disimpulkan bahwa tidak terdapat gejala multikolinearitas pada model regresi dalam penelitian ini.

\section{2) Uji Heteroskedastisitas}

Menurut Ghozali (2012), uji heteroskedastisitasa dilakukan untuk melihat apakah dalam model regresi terdapat ketidaksamaan variance dari 
residual satu pengamatana ke pengamatana yang lain. Jika variance dari residual satu pengamatan ke pengamatan yang lain tetap, maka disebut homoskedastisitas; dan jika berbeda heteroskedastisitas. Model regresi yang tidak memiliki heteroskedastisitas adalah model regresia yang baik. Uji heteroskedastisitas menggunakan metode grafik dengan melihat ada tidaknya pola tertentu pada scatterplot variabel dependen. Jika ada tidak ada pola tertentu tidak ada heteroskedastisitas, dan sebaliknya. Hasil analisis dengan menggunakan SPSS disajikan pada Gambar 12.

Berdasarkan grafik scatterplot petani mangga di Kecamatan Cikedung dan Japara bebas dari gejala heteroskedastisitas karena tidak ada pola dan tersebar secara acak di atas dan di bawah angka 0 . Sehingga dapat disimpulkan bahwa model regresi dalam penelitian ini tidak terjadi heteroskedastisitas dan memenuhi dalam uji asumsi klasik.

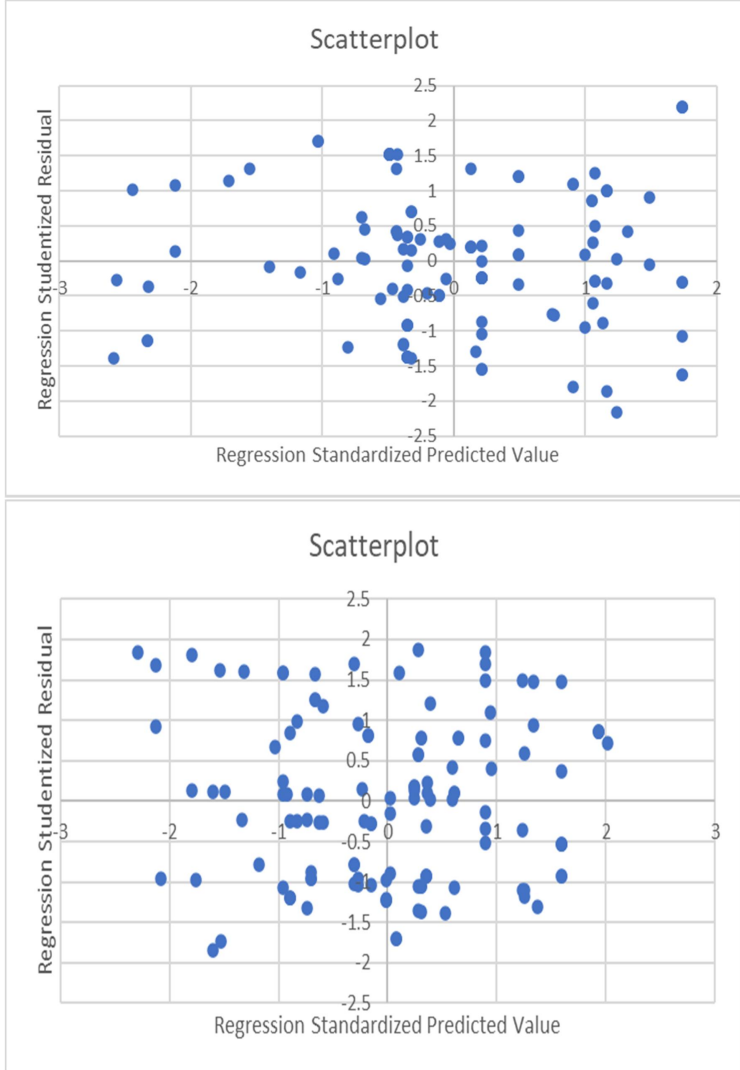

\section{Gambar 12. Hasil Uji Heteroskedastisitas (Atas: Kecamatan Cikedung, Bawah: Kecamatan Japara)}

\section{3) Uji Normalitas}

Uji normalitas dilakukan bertujuan untuk melihat apakah residual yang akan dilakukan penelitian tersebar secara normal atau tidak. Nilai residual tersebar secara normal apabila data menyebar di sekitar grafik histogram atau garis diagonal pada diagram P-P Plot Regression Standarized Residual, sehingga model regresi dapat memenuhi asumsi normalitas (Janie, 2012). Model regresi yang sebaran residual normal atau mendekati normal merupakan model regresi yang baik. 


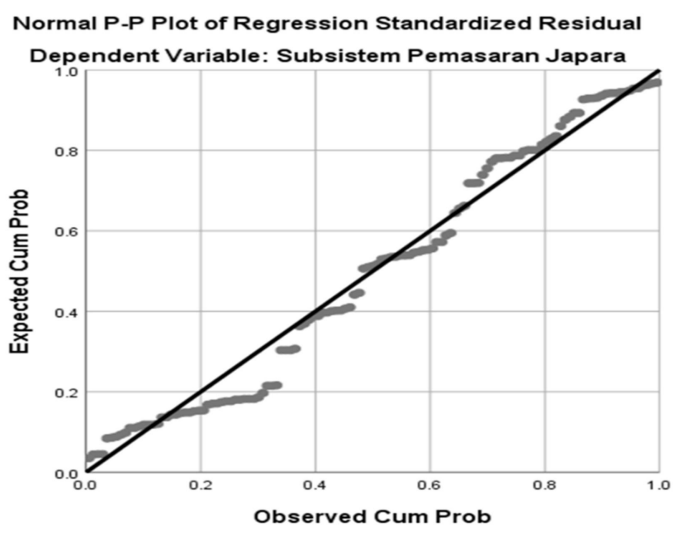

Normal P-P Plot of Regression Standardized Residual

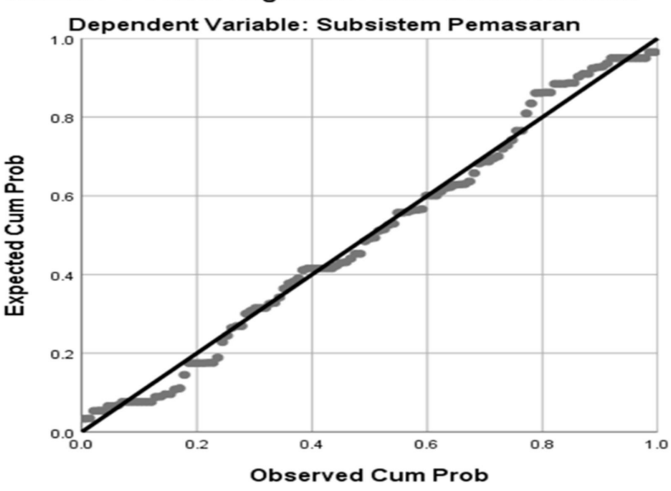

Gambar 13. Hasil Uji Normalitas (Atas: Kecamatan Cikedung, Bawah: Kecamatan Japara)

Uji normalitas dapat dicari melalui SPSS dengan memperhatikan histogram dan plot P-P. Jika histogram dari nilai residu membentuk pola berupa lonceng dengan nilai mean 0 , hal ini menandakan memiliki a distribusi normal. Uji normalitas dengan menggunakan P-P Plot dikatakan berdistribusi normal jika titik titiknya berada di sepanjang garis. Hasil uji normalitas P-P Standardized Residual Plot Regresi disajikan dalam Gambar 13.

Berdasarkan Gambar 13, data petani pada Kecamtan Cikedung dan Kecamatan Japara jika dilihat dari bagan P-P Plot normal, sebaran data berada pada sepanjang garis linier (diagonal). Sehingga dapat diasumsikan bahwa model analisis regresi telah terdistribusi normal dan memenuhi asumsi normalitas.

\section{Uji Goodness of Fit}

\section{1) Koefisien Determinasi $\left(R^{2}\right)$}

Sugiyono (2015) menjelaskan bahwa koefisien determinasi digunakan untuk mengukur besarnya sumbangan variabel bebas terhadap variabel terikat. Nilai koefisien determinasi berada di antara 0 dan 1. Nilai yang semakin mendekati angka 1 maka variabel bebas semakin baik dalam menjelaskan variabel terikat.

Berdasarkan hasil analisis yang dilakukan, pada Kecamatan Cikedung nilai $\mathrm{R}^{2}$ adalah 0,089 yang menunjukan bahwa variasi kenaikan dan penurunan variabel subsistem pemasaran di Kecamatan Jikedung dipengaruhi oleh faktor sosial dan ekonomi sebesar 8,9\% sedangkan 91,1\% lainnya dipengaruhi oleh variabel lainnya yang tidak diteliti pada penelitian ini. Pada kecamatan Japara nilai $\mathrm{R}^{2}$ adalah 0,002 yang menunjukan bahwa variasi kenaikan dan penurunan variabel subsistem pemasaran di Kecamatan Japara dipengaruhi oleh faktor sosial dan ekonomi sebesar 0,2\% sedangkan 99,8\% lainnya dipengaruhi 
oleh variabel lainya yang tidak diteliti pada penelitian ini.

\section{2) Uji F}

Menurut Ghozali (2012), uji goodness of fit (uji kelayakan model) digunakan untuk melihat ketepatan fungsi regresi sampel dalam menaksir nilai aktual secara statistik. Model goodness of fit dapat dilihat dari besaran nilai statistik F yang menunjukkan apakah semua variabel independen yang dimasukkan dalam model mempunyai pengaruh secara bersama-sama terhadap variabel dependen. hasil uji F dikatakan signifikan apabila nilai nilai $p$-value (sig.) < level of significant yang ditentukan $(0,05)$.

Berdasarkan hasil analisis yang dilakukan terhadap data petani di Kecamatan Cikedung memiliki nilai $p$ value $=0,003<0,05$ sehingga dapat disimpulkan bahwa variabel sosial dan ekonomi di Kecamatan Cikedung berpengaruh signifikan terhadap subsistem pemasaran di Kecamatan Cikedung. Pada data petani di Kecamatan Japara, nilai $p$-value $=0.868$ $>0,05$ sehingga dapat disimpulkan bahwa variabel sosial dan ekonomi di Kecamatan Japara berpengaruh tidak signifikan terhadap subsistem pemasaran di Kecamatan Japara.

\section{3) Uji t}

Uji t digunakan untuk mengetahui besarnya pengaruh masing-masing variabel independen secara parsial terhadap variabel dependen. Nilai dari uji $\mathrm{t}$ dapat diketahui dengan melihat $p$-value (sig.) atau nilai t-hitung. Apabila $p$-value lebih kecil dari level of significant yang sudah ditentukan $(0,05)$ atau nilai thitung lebih besar daripada t-tabel maka variabel independen dapat dikatakan berpengaruh nyata terhadap variabel dependen.

Tabel 5. Hasil Uji t

\begin{tabular}{lccc}
\hline \multicolumn{1}{c}{ Variabel } & $\mathbf{t}_{\text {hitung }}$ & p-value & $\begin{array}{c}\text { Koefisien } \\
\text { Regresi }\end{array}$ \\
\hline $\begin{array}{l}\text { Faktor Sosial Cikedung } \\
\left(\mathrm{X}_{1}\right)\end{array}$ & 2,344 & $0,021^{*}$ & 0,175 \\
$\begin{array}{l}\text { Faktor Ekonomi } \\
\text { Cikedung }\left(\mathrm{X}_{2}\right)\end{array}$ & 1,637 & 0,104 & 0,119 \\
\hline $\begin{array}{l}\text { Faktor Sosial Japara } \\
\left(\mathrm{X}_{1}\right)\end{array}$ & 0,220 & 0,826 & 0,016 \\
$\begin{array}{l}\text { Faktor Ekonomi Japara } \\
\left(\mathrm{X}_{2}\right)\end{array}$ & 0,449 & 0,654 & 0,033 \\
\hline $\left.\mathrm{Ket}^{*}\right)$ Signifikan pada taraf nyata 5\% &
\end{tabular}

Ket: *) Signifikan pada taraf nyata $5 \%$

Model persamaan faktor-faktor yang mempengaruhi subsistem pemasaran manga di Kecamatan Cikedung adalah:

$$
\begin{aligned}
Y=7,612+ & 0,175 X 1+0,119 X 2 \\
& +\varepsilon
\end{aligned}
$$

Berdasarkan Tabel 5, diketahui bahwa terdapat satu variabel yang memiliki pengaruh signifikan terhadap subsistem pemasaran mangga di Kecamatan Cikedung, yaitu faktor sosial. 
Berikut ini adalah interpretasi dari hasil analisis $p$-value dari faktor-faktor yang mempengaruhi subsistem pemasaran mangga di Kecamatan Cikedung.

\section{Faktor Sosial $\left(\mathrm{X}_{1}\right)$ Kecamatan Cikedung}

Berdasarkan pada Tabel 5, variabel faktor sosial memiliki $p$-value $=0,021<$ $\alpha=0,05$, dengan koefisien regresi 0,175 . Hal tersebut berarti faktor sosial memiliki pengaruh positif secara signifikan pada taraf nyata 5\% terhadap subsistem pemasaran mangga di Kecamatan Cikedung.

Hal tersebut berarti semakin baik faktor sosial yang terdiri atas rutinitas diskusi antar petani, kerja sama masyarakat, dan jarang terjadi konflik dalam masyarakat, maka semakin baik pula pemasaran mangga di Kecamatan Cikedung.

2. Faktor Ekonomi $\left(\mathrm{X}_{2}\right)$ Kecamatan Cikedung

Variabel faktor ekonomi memiliki $p$-value $=0,104>\alpha=0,05$ dan memiliki koefisien regresi sebesar 0,119. Artinya, faktor ekonomi tidak berpengaruh signifikan terhadap subsistem pemasaran mangga di Kecamatan Cikedung pada taraf nyata $5 \%$.

Faktor ekonomi yang terdiri atas kemudahan akses modal, permintaan mangga tinggi, dan harga jual mangga tinggi, tidak berpengaruh signifikan terhadap pemasaran mangga di Kecamatan Cikedung.

Selanjutnya, model persamaan faktor-faktor yang mempengaruhi subsistem pemasaran mangga di Kecamatan Japara adalah sebagai berikut:

$$
\begin{gathered}
Y=10,71+0,016 X 1+0,033 X 2 \\
+\varepsilon
\end{gathered}
$$

Berdasarkan Tabel 5, diketahui bahwa kedua variabel memiliki pengaruh tidak signifikan pada subsistem pemasaran mangga di Kecamatan Japara. Berikut ini adalah interpretasi dari hasil analisis $p$-value dari faktor-faktor yang mempengaruhi subsistem pemasaran mangga di Kecamatan Japara.

\section{Faktor Sosial $\left(\mathrm{X}_{1}\right)$ Kecamatan Japara}

Berdasarkan pada Tabel 5, variabel faktor sosial memiliki $p$-value $=0,826>$ $\alpha=0,05$, dengan koefisien regresi 0,016. Hal tersebut berarti faktor sosial memiliki pengaruh positif namun tidak signifikan pada taraf nyata $5 \%$ terhadap subsistem pemasaran mangga di Kecamatan Japara.

Faktor sosial yang terdiri atas rutinitas diskusi antar petani, kerja sama masyarakat, dan jarang terjadi konflik dalam masyarakat, tidak berpengaruh signifikan terhadap pemasaran mangga di Kecamatan Japara. 
2. Faktor Ekonomi $\left(\mathrm{X}_{2}\right)$ Kecamatan Japara

Variabel faktor ekonomi memiliki $p$-value $=0,654>\alpha=0,05$ dan memiliki koefisien regresi sebesar 0,033. Artinya, faktor ekonomi tidak berpengaruh signifikan terhadap subsistem pemasaran mangga di Kecamatan Japara pada taraf nyata $5 \%$.

Faktor ekonomi yang terdiri atas kemudahan akses modal, permintaan mangga tinggi, dan harga jual mangga tinggi, tidak berpengaruh signifikan terhadap pemasaran mangga di Kecamatan Japara.

Hasil penelitian faktor sosial dan faktor ekonomi yang mempengaruhi pemasaran pada penelitian ini berbeda dengan hasil penelitian yang dilakukan oleh Teka et al. (2019) di Distrik Gomma, Ethiopia yang menunjukan bahwa dalam pemasaran mangga sangat dipengaruhi oleh faktor sosial ekonominya. Begitu juga dengan penelitian yang dilakukan oleh Ojedukun (2019) di Negara Bagian Oyo, Nigeria yang menjelaskan bahwa dalam pemasaran mangga yang dilakukan oleh petani, dipengaruhi oleh faktor sosial ekonomi. Dalam penelitian ini, hanya faktor sosial di Kecamatan Cikedung saja yang berpengaruh secara signifikan pada pemasaran mangga. Selain itu, faktor ekonomi di Kecamatan Cikedung serta faktor sosial dan faktor ekonomi di Kecamatan Japara tidak berpengaruh secara signfikan. Perbedaan ini diduga karena terdapat perbedaan pada indikator variabel faktor sosial dan faktor ekonomi yang digunakan dalam penelitian ini dengan penelitian yang dilakukan oleh Teka (2019) dan Ojedukun (2019).

Faktor sosial berpengaruh secara signifikan terhadap pemasaran pada Kecamatan Cikedung karena indikator faktor sosial yang terdiri atas rutinitas diskusi antar petani, kerja sama antar masyarakat atau petani mangga, dan jarang terjadi konflik dalam masyarakat, mampu mempengaruhi pemasaran mangga yang dilakukan oleh petani di Kecamatan Cikedung. Diduga ketika petani sering melakukan diskusi dan kerja sama antar petani maka pengetahuan petani terhadap informasi pemasaran dan informasi harga pasar dapat bertambah dan dapat meningkatkan posisi tawar petani, hal ini juga membuat petani di Kecamatan Cikedung mayoritas telah mengetahui informasi harga pasar.

Faktor ekonomi tidak berpengaruh secara signfikan terhadap pemasaran pada Kecamatan Cikedung karena indikator faktor ekonomi yang terdiri atas kemudahan akses modal, permintaan 
mangga tinggi, dan harga jual mangga tinggi, tidak mampu dalam mempengaruhi pemasaran yang dilakukan oleh petani di Kecamatan Cikedung secara signifikan. Faktor eknonomi tidak berpengaruh signifikan diduga karena mayoritas petani di Kecamatan Cikedung menjual produknya melalui pedagang pengumpul/tengkulak, ketika harga jual mangga tinggi ataupun permintaan mangga sedang tinggi tidak mempengaruhi petani di Kecamatan Cikedung karena mayoritas petani menjual produknya ke pedagang pengumpul/tengkulak dan harga jual juga mayoritas ditentukan oleh pembeli bukan petani.

Faktor sosial tidak berpengaruh secara signifikan pada pemasaran di Kecamatan Japara karena indikator faktor sosial yang terdiri atas rutinitas diskusi antar petani, kerja sama antar masyarakat atau petani mangga, dan jarang terjadi konflik dalam masyarakat, tidak mampu mempengaruhi kegiatan pemasaran yang dilakukan oleh petani di Kecamatan Japara secara signifikan. Faktor sosial tidak berpengaruh signifikan diduga karena meskipun petani sering melakukan diskusi antar petani serta kerja sama antar petani, tetapi minimnya informasi yang dimiliki oleh petani membuat mayoritas petani di Kecamatan Japara mayoritas belum mengetahui informasi harga pasar sehingga faktor sosial di Kecamatan Japara tidak mampu mempengaruhi petani dalam melakukan pemasaran.

Faktor ekonomi tidak berpengaruh secara signfikan terhadap pemasaran pada Kecamatan Cikedung karena indikator faktor ekonomi yang terdiri atas kemudahan akses modal, permintaan mangga tinggi, dan harga jual mangga tinggi, tidak mampu dalam mempengaruhi pemasaran yang dilakukan oleh petani di Kecamatan Cikedung. Diduga Petani di Kecamatan Japara mayoritas menjual produknya kepada pedagang pengumpul atau tengkulak sehingga ketika harga sedang tinggi atau rendah atau permintan mangga sedang tinggi atau rendah di masyarakat petani tetap menjual produknya kepada pedagang pengumpul/tengkulak.

\section{KESIMPULAN}

Petani mangga di Kecamatan Cikedung dan Japara mayoritas berpersepsi terkait faktor sosial dan faktor ekonomi yaitu rutinitas diskusi antar petani mangga baik, kerja sama yang dilakukan antar petani mangga baik dan jarang terjadi konflik antar 
masyarakat dan petani mangga, akses terhadap modal mudah, permintaan mangga tinggi dan harga jual mangga relatif tinggi.

Mengenai pemasaran mangga, petani di Kecamatan Cikedung dalam penentuan harga lebih banyak ditentukan oleh pembeli dibandingkan dengan petani di Japara. Petani Japara yang menjual ke pedagang pengumpul atau tengkulak lebih banyak dari pada petani Cikedung. petani di Cikedung memiliki informasi harga pasar lebih banyak dari pada petani di Japara. Kebun mangga petani di Cikedung mayoritas sudah bisa diakses oleh mobil sementara di Japara mayoritas belum bisa diakses oleh mobil.

Pada Kecamatan Cikedung faktor sosial yang terdiri atas rutinitas diskusi antar petani mangga, kerja sama yang dilakukan antar petani mangga dan jarang terjadi konflik antar masyarakat dan petani mangga, berpengaruh secara signifikan pada pemasaran mangga di Kecamatan Cikedung. Sementara itu di Kecamatan Cikedung faktor ekonomi yang terdiri atas kemudahan akses terhadap modal, tingginya permintaan mangga dan harga jual mangga tinggi, tidak berpengaruh signifikan. Pada Kecamatan Japara faktor sosial dan faktor ekonomi keduanya tidak berpengaruh signifikan terhadap pemasaran mangga di Kecamatan Japara.

\section{DAFTAR PUSTAKA}

[Badan Pusat Statistik Kabupaten Indramayu]. 2020. Kecamatan Dengan Produksi Mangga Terbesar di Indramayu.

[BPS]. 2019. Produktivitas Mangga Provinsi Jawa Barat, Jawa Tengah dan Jawa Timur.

[Dinas Tanaman Pangan dan Holtikultura Jawa Barat]. 2020. Produksi Mangga di Sentra Mangga Jawa_Barat Tahun 2018.

Andriani, R., Rasmikayati, E., Mukti, G. W., \& Fatimah, S. (2019). Faktorfaktor yang Mempengaruhi Keputusan Petani Mangga dalam Pemilihan Pasar di Kabupaten Indramayu. Jurnal Penyuluhan, 15(2), 286-298.

Awaliyah, F., \& Saefudin, B. R. (2020). Efisisensi Pemasaran Komoditas Mangga Gedong Gincu Di Kabupaten Cirebon. Paradigma Agribisnis, 3(1), 1-11.

Azizah, M. N., Rasmikayati, E., \& Saefudin, B. R. (2019). Perilaku budidaya petani mangga dikaitkan dengan lembaga pemasarannya di Kecamatan Greged Kabupaten Cirebon. Jurnal Ilmiah Mahasiswa Agroinfo Galuh, 5(1), 987-998.

Ghozali, I. (2012). Aplikasi Analisis Multivariate dengan Program IBM SPSS.

Janie, D. N. A. (2012). Statistik deskriptif \& regresi linier berganda dengan SPSS. Jurnal, April.

Kabeta, T. (2018). Value Chain Analysis of Teff (Eragrostistef (Zucc): The Case of Jimma Arjo District, East Wollega Zone, Oromia Region, Ethiopia (Doctoral dissertation). 
Kusumo, R. A. B., Rasmikayati, E., Karyani, T., \& Mukti, G. W. (2019). PERBANDINGAN PERILAKU USAHATANI PADA DUA SENTRA PRODUKSI MANGGA DI PROVINSI JAWA BARAT (Kasus di Kabupaten Indramayu dan Kuningan). Mimbar Agribisnis: Jurnal Pemikiran Masyarakat Ilmiah Berwawasan Agribisnis, 5(2), 134-144.

Ojedokun, I.K., \& Oladejo, J.A. (2019). Economic Status of Mango Marketing in Ogbomoso Agricultural Zone Area of Oyo State, Nigeria. International Journal of Research and Scientific Innovation (IJRSI).

Rachmah, A. D., Rasmikayati, E., \& Saefudin, B. R. (2019). Factors related to continuation of mango cultivation. Jurnal Pertanian, 10(2), 52-60.

Rasmikayati, E., Azizah, M. N., \& Saefudin, B. R. (2019). Potensi dan Kendala yang Dihadapi Petani Mangga dalam Mengakses Lembaga Pemasaran (Studi Kasus Di Kecamatan Greged Kabupaten Cirebon). Paradigma Agribisnis, 2(1), 22-30.

Rasmikayati, E., Elfadina, E. A., \& Saefudin, B. R. (2019). Characteristics of Mango Farmers and Factors Associated with Their Land Tenure Area. International Journal of Scientific and Research Publication (IJSRP), 9(9), 758-765.
Rasmikayati, E., Kusumo, R. A. B., Sukayat, Y., Arisyi, Y. H., \& Saefudin, B. R. (2020). Karakteristik Individu Dan Usahatani Petani Mangga Yang Melakukan Kemitraan Pemasaran Di Kecamatan Sindangkasih Kabupaten Majalengka. Paradigma Agribisnis, 3(1), 12-23.

Sari, A. F., Rasmikayati, E., \& Saefudin, B. R. (2019). Behavioral Dynamics of Farmers and First Buyer in Marketing Mangoes in Sedong District, Cirebon Regency, West Java. Agrifor: Jurnal Ilmu Pertanian dan Kehutanan, 18(1), 63-72.

Shinta, A. (2001). Ilmu Usaha Tani. Universitas Brawijaya Press.

Sugiyono. (2007). Statistik Untuk Penelitian. Bandung: ALFABETA.

Supriatna, A. (2008). Kinerja dan Prospek Pemasaran Komoditas Mangga (Studi Kasus Petani Mangga Di Propinsi Jawa Barat). SOCA: Jurnal Sosial Ekonomi Pertanian.

Teka, Y., Malin, H., \& Wolde, A. O. (2019). Analysis of factors affecting mango market supply in Gomma district, Southwest Ethiopia. Agricultural SocioEconomics Journal, 19(3), 181190.

Yuliawati, Y. (2018). SALURAN PEMASARAN UBI JALAR (dari Desa Bandorasa Kulon Kabupaten Kuningan Sampai Ke Pasar Cikurubuk Tasikmalaya) (Doctoral dissertation, Universitas Siliwangi). 